\title{
INFLUENCE OF COMPETITIVENESS, CORRUPTION AND FOREIGN DIRECT INVESTMENT ON ECONOMIC GROWTH OF ASEAN DEVELOPING COUNTRIES
}

\author{
Fadeli Yusuf Afif ${ }^{1}$ and Ukhti Ciptawaty ${ }^{2)}$ \\ Faculty of Economic and Business, University of Lampung \\ 1) fadeliyusufafif1005@gmail.com, ${ }^{2)}$ ciptawaty@gmail.com
}

\begin{abstract}
The purpose of this study is to look at the condition of the country's competitiveness and its influence on ASEAN economic growth. The data used is panel data consisting of time series data for $2009-2019$ and cross section of five ASEAN countries with the highest level of competitiveness. The variables used are economic growth, competitiveness, corruption perception index, political risk, and foreign direct investment. The analysis tool used is panel data regression, the Random Effect Model (REM). The results show that competitiveness and foreign direct investment have a positive and significant effect on economic growth, while the corruption perception index has no effect on economic growth in 5 ASEAN countries.
\end{abstract}

Keywords: ASEAN, Competitiveness, Corruption, Economic Growth and Foreign Direct Investment.

\section{INTRODUCTION}

Economic growth can be interpreted as a process of changing a country's economic conditions on an ongoing basis towards a better condition that is a physical increase in the production of goods and services in force in a country. The success of the performance of the government and related institutions and agencies of the economy are measured by the economic growth produced. Therefore economic growth becomes important in assessing the success of a country in achieving economic development during a certain period.

The problem of economic growth increases when there is a population explosion. Economic growth is a process of increasing output continuously in the long term, high and sustainable economic growth is an important condition or something that is imperative for the continuity of economic development and increasing welfare (Machmud, 2016).

Economic growth is a prerequisite for achieving human development because economic development is guaranteed to increase productivity and increase income through the creation of employment opportunities. The relatively high level of human development will affect the performance of economic growth through the capability of the population and the consequence is increased productivity and creativity of the community. With increased productivity and creativity, the population can absorb and manage the resources that are important for economic 
growth.

One theory of economic growth is the Solow Theory (1956). The importance of the role of Human Resources in the Solow Theory is inseparable from the competitiveness of its Human Resources. Competitiveness can be measured by indicators including: institutions, infrastructure, macroeconomic environment, basic health and education, education and training, market efficiency, labor market efficiency, financial market developments, technology availability, market size, business updates, and innovation. In other words, indicators in contributing to competitiveness are a reflection of the economic growth of the Solow Model.

Competitiveness is one of the criteria to increase income and economic growth of a country. The results of a World Bank survey and The World Economic Forum (WEF), competitiveness affects a country's economic growth (Schwab, 2020). Some empirical studies on competitiveness towards economic growth are described below: Mihaela (2016), Petrariu, Robert, and Radu (2013), Chung (2011), Verner (2015), Pilinkiene (2016) ), \& Webster and Stanislav (2014) examine the relationship of daylight to economic growth. The results of the study stated that the competitiveness of a country has a positive and significant effect on the country's economic growth.

In addition to competitiveness, economic growth is also influenced by governance including controlling corruption. Corruption is still a hot global issue today. Corruption causes losses in various sectors, where the impact is pressing a country's economic growth (Machmud, 2016). Eradicating corruption as a core goal of Sustainable Development Goals (SDG's), because of its impact that can affect the economy and economic development. Based on the report of the Corruption Perception Index from Transparency International (2018) that "not one single country, anywhere in the world, is corruption-free" which means that no country is truly free from corruption. Corruption can weaken the country's ability to provide inclusive economic growth because it will disrupt macro stability, investment, capital accumulation, and productivity.

Corruption Perception Index (IPK) is an indicator of corruption. Corruption Perception Index uses a scale from 0-100. If the GPA score approaches "0" it means that the level of corruption in the country is very high and vice versa. Several studies on the index of corruption perceptions of economic growth are explained as follows: Boris, Jia; Djuro, and Stanley (2008), and Toke, Jayasri; Vania (2008) shows that an increase in corruption control or corruption perception index causes an increase in GDP per capita growth rate. While Zvika, Daniele, Avi (2008) stated that in an open economy, corruption is negatively related.

In addition to competitiveness and corruption, economic growth is also influenced by investment. Foreign Direct Investment plays an important role in driving the level of economic growth. Foreign Direct Investment technology from more developed countries and therefore plays a leading role in technological improvement for recipient countries. This means that Foreign Direct Investment can accelerate economic growth because the incoming foreign investment can add to factors of domestic production to be better in quality and quantity (Rohmana, 2010).

Some research on Foreign Direct Investment are as follows: Dkhili and Lassad (2018), Alzaidy, Mohd and Zakaria (2017), Alfaro, Areendam, Sebnem, and Selin Sayek (2004) and (2010), Mehdi (2012), and Riyad (2012) examine the relationship between Foreign Direct Investment and economic growth. The results show that the Foreign Direct Investment variable has a positive and significant effect on the variable of economic growth. While Alfaro (2003) states that Foreign Direct Investment has a negative and significant effect on economic growth. 
Therefore, the main research objective is to analyze the effect of country competitiveness on economic growth in 5 ASEAN countries. Other objectives are to analyze the effect of the corruption perception index on economic growth in 5 ASEAN countries, and analyze the effect of Foreign Direct Investment on economic growth in 5 ASEAN countries.

\section{LITERATURE REVIEW}

\section{Theoretical Review}

\section{Economic Growth}

The neo-classical growth theory was developed by Solow and Swan (1956). The SolowSwan model uses elements of population growth, capital accumulation, technological progress (exogenous), and the amount of interacting output. Solow- Swan uses a production function model that allows for a substitution between capital $(\mathrm{K})$ and labor $(\mathrm{L})$. Growth rates come from three sources: capital accumulation, increased labor supply, and technological progress.

Mankiw (2006) The supply of goods in the Solow model is based on a well- known production function, which states that output depends on capital stock and labor force. $\mathrm{Y}=\mathrm{f}(\mathrm{K}, \mathrm{L}, \mathrm{A})$

The Solow growth model assumes that the production function is via a constant return scale or constant returns to scale. This assumption is often considered realistic, as we will see below, this assumption helps to simplify the analysis.

\section{Competitiveness}

Competitiveness is one of the criteria for determining the success and achievement of a better goal by a country in increasing income and economic growth. Competitiveness is identified with productivity problems, namely by looking at the level of output produced for each input used. Increased productivity is caused by an increase in the amount of physical input of capital and labor, an increase in the quality of the inputs used and an increase in technology (Porter, 1990 in Abdullah, 2002).

Michael Porter (1990) states that the concept of competitiveness that can be applied at the national level is "productivity" which is defined as the value of output produced by a workforce. The World Bank stated relatively the same thing in which "competitiveness refers to the magnitude and rate of change in value added per unit of input achieved by the company".

\section{Corruption}

Klitgaard simply models the factors that cause corruption, namely Corruption is the same as monopoly power plus the authority of officials (Discretion by officials) less accountability (Accountability) or can also be formulated as:

$\mathrm{C}=\mathrm{M}+\mathrm{D}-\mathrm{A}(2)$

To measure a level of corruption needs to be agreed in advance how we interpret corruption. Corruption is difficult to quantify, but we can know it when we see it (Wei: 2000).

Corruption Perception Index (CPI) is an index created by Transparency International to measure or quantify corruption in a country. This index ranks countries on a scale of 1 to 10 , but the scale has now been changed to 1 to 100 . CPl is based on a 10 point scale where a scale of 10 indicates very little corruption and a score of 1 indicates a very corrupt government 
(Transparency International, 2019).

\section{Foreign Direct Investment}

Economic theory defines or defines investment as expenditures to buy capital goods and production equipment with the aim of replacing and especially adding capital goods in the economy that will be used to produce goods and services in the future. Investment often leads to changes in overall demand and affects the business cycle, while investment leads to capital accumulation which can increase the country's potential output and develop long-term economic growth (Samuelson, 2003).

\section{Empirical Review}

There are several studies that have been carried out to examine daylight, corruption perception index, and Foreign Direct Investment on economic growth including: Mihaela (2016), Petrariu, Ioan R, Robert Bumbac, and Radu Ciobanu (2013), Chung (2011), Verner (2015), Pilinkiene (2016), and Webster, Craig and Stanislav Ivanov (2014) who examined the country's competitiveness towards economic growth. The results showed that the results showed that the country's competitiveness had a positive and significant effect on economic growth.

Grundler, and Niklas (2019), Huang (2015), Mauro (1995), Rock, and Haeidi (2003), and Tanzi and Hamid (1997) examine the effect of the corruption perception index on economic growth, the results show that the corruption perception index has a positive and significant effect on the country's economic growth. Meanwhile, Toke, Jayasri, and Vania (2008) showed that the corruption perception index had a negative and significant effect on economic growth.

Dkhili and Lassad (2018), Alzaidy, Mohd and Zakaria (2017), Mehdi (2012), Riyad (2012), Alfaro, Areendam, Sebnem, and Selin (2010), Alfaro, Areendam, Sebnem, and Selin (2004), and Alfaro (2003) examine the influence of Foreign Direct Investment on economic growth, the results show that Foreign Direct Investment has a positive effect and significant to economic growth.

\section{METHODS}

\section{Types and Sources of Data}

This type of research is quantitative descriptive. The data used in this study are secondary data consisting of time series and annual cross section data for the period 2009 to 2019 in five ASEAN countries, namely Malaysia, Indonesia, Thailand, Vietnam and the Philippines. The selection of these countries is based on ASEAN countries that are classified as developing countries with the highest five competitiveness values in 2019, while the study began in 2009 because the author wants to analyze economic growth after the 2008 global crisis. Data obtained from the World Bank, Transparency International, and The Global Competitiveness Report.

\section{Economic Model Specifications}

The economic growth model used in this study, the Solow Model (1956), is as follows;

$\mathrm{Y}=\mathrm{f}(\mathrm{K}, \mathrm{L}, \mathrm{A})$

Where,

$\mathrm{K}=$ Capital $\mathrm{L}=$ Labor $\mathrm{A}=$

Technology 
The capital component (K) in this study is proxied in Foreign Direct Investment, while labor (L) and technology (A) are proxied in competitiveness. Corruption variables are proxied on the perception index of the corpusion (Mihaela, 2016). Next, the model is transformed into the panel data regression equation model:

PEit $=$ P0 + PtDSNit + P2 IPKit + PsFDIit + ett

Where:

$$
\begin{aligned}
& \text { PEit = Economic Growth (Percent) } \\
& \mathrm{Pi} \quad=\text { Constant } \\
& \text { DSNit = Competitiveness (Points) } \\
& \text { IPKit = Corruption Perception Index (Points) } \\
& \text { FDIit = Foreign Direct Investment (Percent) } \\
& \begin{array}{ll}
\text { Sit } \quad=\text { error term } \\
\mathrm{i} \quad=1,2, \ldots . \mathrm{n}, \text { number of cross sections } \\
\mathrm{t} & =1,2, \ldots . \mathrm{t}, \text { the time series dimension }
\end{array}
\end{aligned}
$$

\section{Data Analysis Methods}

The analytical tool used in this study is the panel data method (pooled data), in conducting this research researchers used the help of the E-Views analysis tool 9. The estimation using panel data generally uses one of three calculation methods, namely the Pooled Least Square method ( PLS), Fixed Effect (FEM) method, and Random Effect (REM) method.

\section{Selection of Panel Data Regression Method}

Panel data estimation which consists of 3 types of methods namely Common Effect (PLS), Fixed Effect (FEM), and Random Effect (REM). Of course in testing required to choose the best modeling. So there are two commonly used test methods, namely the Chow test (testing conducted to choose the best approach model between Common Effect and Fixed Effect) and the Hausman test (this test is to choose the best model between Fixed Effect or Random Effect), and Breusch Test -Pagan (this test is to choose the best model between the Common Effect or Random Effect).

\section{Classical Assumption Testing}

\section{a. Multicollinearity Test}

Multicollinearity test is to test whether the regression model found a correlation between independent variables. If there is a correlation, it is called the multicollinearity problem. With the rule of thumb, if the correlation coefficient 0.80 , it can be concluded that there is a multicollinearity problem in the model used (Farrar, D.E. and Robert R. Glauber, 1967).

\section{b. Heteroscedasticity Test}

Heteroscedasticity is one of the deviations from the assumption that variance (homoskedasticity) is not constant. The quickest way to test the problem of heteroscedasticity is to detect residual patterns through a graph. If the residue has the same variant (homoscedasticity) or the data do not form a pattern. Conversely, if the residual has heteroscedasticity, then this residual will form a certain pattern (Rosopa, Patrik J and Meline M. Schaffer, 2013).

\section{Statistical Hypothesis Testing}

a. Partial Test (t-test)

$\mathrm{T}$ test is used to see the significance of the effect of each independent variable on the 
dependent variable at $\mathrm{a}=5 \%$ assuming the other variables are considered fixed. In this case the value will be between t-count and t table (Ugoni, Antony and Bruce F. Walker, 1995).

\section{b. Test F Statistics}

The overall significance test is carried out through the statistical test $\mathrm{f}$ (simultaneous significance test). To test whether the regression coefficients pi and $\mathrm{p} 2$ together or overall affect the dependent variable at $\mathrm{a}=5 \%$ (Box G.E.P., 1953).

\section{RESULTS AND DISCUSSION}

\section{Model Significance Test}

\section{a. Chow Test Results}

Chow test is a test conducted to choose the best approach model between the Common Effect Model and the Fixed Effect Model (Widarjono, 2018).

Table 1. Chow Test Results

\begin{tabular}{lcll}
\hline Effects Test & Statistic & d.f. & Prob. \\
\hline Cross-section F & 9,937015 & $(4,47)$ & 0,0000 \\
Cross-section Chi-square & 33,707324 & 4 & 0,0000 \\
\hline
\end{tabular}

Source: Output Eviews 9.0

Table 1 shows that the value of Prob. Cross-section F of 0.0000 is smaller than the real level (a) of 5 percent, $(0.0000<0.05)$ then $\mathrm{H} 0$ is rejected and accepts Ha so it can be concluded that the Fixed Effect Model (FEM) method is better than the method Common Effect Model (CEM).

\section{b. Hausman Test Results}

Hausman Test is a test conducted to compare and choose between Random Effect (REM) and Fixed Effect (FEM).

Table 2. Hausman Test Results

\begin{tabular}{llll}
\hline Test Summary & Chi-Sq. Statistic & Chi-Sq. d.f & Prob. \\
\hline Cross-section random & 5,242662 & 3 & 0,1549 \\
\hline
\end{tabular}

Source: Output Eviews 9.0

Table 2 shows that the p-value of 0.1549 is greater than the a significance level of $5 \%$ (0.05), so it can be concluded that the random effect (REM) method is better used than the fixed effect (FEM) method.

\section{c. Significance Test (LM-Pagan Breusch Test)}

Breusch-Pagan Lagrange Multiplier (LM) test was carried out to choose the best method between Common Effect (CEM) and Random Effect (REM).

Table 3. LM-Test Results

\begin{tabular}{llll}
\hline Test Hypothesis & Cross-section & Time & Both \\
\hline Breusch-Pagan & 14,15076 & 3,418750 & 17,56951 \\
& $(0,0002)$ & $(0,0645)$ & $(0,0000)$ \\
\hline
\end{tabular}

Source: Output Eviews 9.0 
Table 3 shows that the Breusch-Pagan BP probability value of $0.0000<0.05$ shows that the Random Effect (REM) method is better than the Common Effect (CEM) method. So it can be concluded that this research uses the Random Effect Model (REM) method.

\section{Random Effect Model Regression Results}

The results of Random Effect Model, as follows:

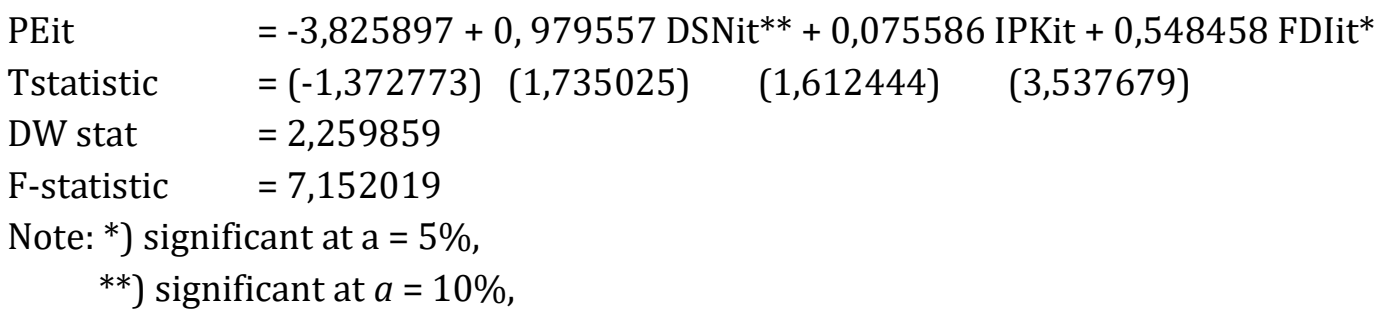

The results above show that the constant coefficient value is - 3.825897, this explains that when all variables are equal to zero, then economic growth is -3.825897 . While the coefficient of the variable state competitiveness of 0.979557 with a probability of 0.0888 is smaller than $\mathrm{a}=10 \%$, this shows that the country's competitiveness has a positive and significant effect on economic growth. Where if there is an increase in the country's competitiveness by 1 point, it will increase economic growth by 0.979557 percent.

Furthermore, the variable coefficient of Corruption Perception Index of 0.075586 with a probability of 0.1130 is greater than $a=5 \%$ or $10 \%$, this shows that the Corruption Perception Index has no effect on economic growth. While the variable coefficient of Foreign Direct Investment is 0.548458 with a probability of 0.0009 smaller than a $=5 \%(0.05)$, this shows that Foreign Direct Investment has a positive and significant effect on economic growth. Where if there is an increase in Foreign Direct Investment by 1 percent, it will increase economic growth by 0.548458 percent.

Those results are in accordance with Mihaela (2016), Petrariu, Robert, and Radu (2013), Chung (2011), Verner (2015), Pilinkiene (2016), \& Webster and Stanislav (2014) who shows that the results show that the country's competitiveness has a positive and significant effect on economic growth.

Dkhili and Lassad (2018), Alzaidy, Mohd and Zakaria (2017), Mehdi (2012), Riyad (2012), Alfaro, Areendam, Sebnem, and Selin (2010), Alfaro, Areendam, Sebnem, and Selin (2004), and Alfaro (2003) who show that Foreign Direct Investment has a positive and significant effect on economic growth.

\section{Classical Assumption Test Results}

\section{a. Multicollinearity Test Results}

Based on the multicollinearity test results, there are no variables that have a value of more than 0.85 . This means that the variables used are not multicollinearity, or in other words there is no linear relationship between the independent variables used in this research. 
Table 4. Multicollinearity Test Results

\begin{tabular}{cccc}
\hline & DSN & IPK & FDI \\
\hline DSN & 1 & 0,70924 & 0,05379 \\
IPK & 0,70924 & 1 & 0,05951 \\
\hline FDI & 0,05379 & 0,05951 & 1 \\
\hline
\end{tabular}

Source: Processed Eviews 9.0

\section{b. Heteroscedasticity Test Results}

Based on the graph method, it can be seen that the residual does not show a certain pattern, so it can be concluded that the detected residual does not show heteroscedasticity.

\section{Statistical Hypothesis Test}

\section{a. t-test (Partial Test)}

This test aims to determine the effect of each variable of community direct assistance and community self-help partially on the number of villages left behind. By using a significance of $5 \%(a=0.05)$, and df $(n-k-1)=51$ obtained a t-table of 1.67528 .

Table 5. T-Test Results

\begin{tabular}{lcll}
\hline Variabel & t-statistic & t-table & Note \\
\hline DSN & 1,735025 & 1,67528 & tolak H0 \\
IPK & 1,612444 & 1,67528 & terima H0 \\
FDI & 3,537679 & 1,67528 & tolak H0 \\
\hline
\end{tabular}

Source: Eviews Results 9.0

\section{b. F-statistic test}

In testing the F-statistic value in this study, a value of 7.152019 was greater than the Ftable value at the significance level $(\square)$ of $5 \%$ ie 3.18 so that HO was rejected and Ha was accepted. Thus it can be concluded that the daytime power, Corruption Perception Index, and Foreign Direct Investment together affect economic growth.

\section{CONCLUSIONS}

Based on the results of data processing and discussions that have been carried out, it can be concluded that competitiveness and Foreign Direct Investment have a positive and significant effect on economic growth, while the Corruption Perception Index has no effect on economic growth in 5 ASEAN countries in 2009-2018.

In an effort to increase economic growth, for policy makers need to pay attention to noneconomic factors such as the competitiveness of a country. Increasing the independent variable will increase economic growth. In addition, economic variables such as Foreign Direct Investment also need to be considered in increasing the economic growth of the five ASEAN countries.

\section{REFERENCES}

Abdullah, Piter, Armida S Alisjahbana, Nurry Effendi and Boediono. 2002. Regional Competitiveness. BPFE. Yogyakarta

Alfaro, Laura. 2003. Foreign Direct Investment and Growth: Does the Sector Matter ?. Harvard Business School Journal. 
Alfaro, Laura, Areendam Chanda, Sebnem Kalemli-Ozcan, and Selin Sayek. 2004. FDI and Economic Growth: The Role of Local Financial Markets. Journal of International Economics, 64 89-112

Alfaro, Laura, Areendam Chanda, Sebnem Kalemli-Ozcan, and Selin Sayek. 2010. How Does Foreign Direct Investment Promote Economic Growth? Exploring the Effects of Financial Markets on Linkages. Journal of Development Economics 91, 242-256

Alzaidy, Ghaith, Mohd Naseem Bin Niaz Ahmad and Zakaria Lacheheb. 2017. The Impact of Foreign Direct Investment on Economic Growth in Malaysia: The Role of Financial Development. International Journal of Economics and Financial Issues, 7 (3), 382-388.

Behname, Mehdi. 2012. Foreign Direct Investment and Economic Growth: Evidence from Southern Asia. Atlantic Review of Economics, Vol. 2

Boris, Podobnik, Jia Shao, Djuro Njavro, and H.E. Stanley. 2008. Influence of Corruption on Economic Growth Rate and Foreign Direct Investment. The European Physical Journal, B 63, 547-550 EDP Science

Chung, Sungchul. 2011. Innovation, Competitiveness, and Growth: Korean Experiences. Journal of the Science and Technology Policy Institute (STEPI).

Dkhili, Hichem and Lassad Ben Dhiab. 2018. The Relationship between Economic Freedom and FDI versus Economic Growth: Evidence from the GCC Countries. Journal of Risk and Financial Management.

Durbin, J., \& G.S. Waston (1951). Testing of Serial Correlation in Least-Squares Regression. Biometrika, Vol. 38, No.1 / 2, pp.159-177

Farrar, D.E., \& Robert R.G. (1967). Multicolinierity In Regression Analysis: The Problem Revisited. Review of Economic and Statistics, Vol. 49, pp.92-107

Jarque, C.M., \& A.K. Fallow. (1987). Test of Normality and Residuals regression. International Statistical Reviews, Vol. 55, pp. 163-172

Machmud Amir. 2016. Indonesian Economy. Erlangga Jakarta

Mankiw, N Gregory. 2006. Macroeconomics, Translation: Fitria Liza, Imam Nurmawan. Jakarta: Erlangga.

Mihaela, Simionescu. 2016. Competitiveness and Economic Growth in Romanian Regions. Journal of Competitiveness. Vol. 8, Issue 4, pp. 46 - 60.

Porter, M. 1990. The Competitive Advantage of Nations. New York: The Free Press.

Petrariu, Ioan R, Robert Bumbac, and Radu Ciobanu. 2013. Innovation: a Path to Competitiveness and Economic Growth. The Case of CEE Countries. Theoretical and Applied Economics. Volume XX, No. 5 (582), pp. 15-26

Pilinkiene, Vaida. 2016. Trade Openness, Economic Growth and Competitiveness. The Case of the Central and Eastern European Countries. Inzinerine Economics-Engineering Economics, 27 (2), 185-194

Porter, M. et, al. 2012. The Determinant of National Competitiveness. NBER Workinng Paper No. 18249. Cambridge, MA: National Bureau of Economic Research.

Riyad, Mohamad. 2012. Factors affecting Economic Growth in Six ASEAN Countries from 1990 to 2009. Journal of Economics and Business. Faculty of Economics, University of Indonesia

Rosopa, P.J., \& Meline M.S. (2013). Managing Heteroscedasticity in General Linear Models. Psychological Methods, Vol. 18 No. 3, 335-351

Samuelson, Paul A and Nordhaus. 2001. Macroeconomics. Jakarta: PT. Educational Media

Schwab, Klaus. 2020. The Global Competitiveness Report 2019. World Economic Forum.

Schwab, Klaus. 2019. The Global Competitiveness Report 2018. World Economic Forum.

Transparency International. 2019. www.transpatenciinternational.org

Toke A, Jayasri D, and Vania S. 2008. Governance Regimes, Corruption and Growth: Theory and Evidence. Journal of Comparative Economics 36195220.

Ugoni, A., \& Bruce F.W. (1995). The t Test. Comsig Review, Vol 4, No. 2

Verner, Tomas. 2015. The Effect of Economic Freedom on National Competitiveness: Causality from a Panel of Countries. Journal of Economics, Business and Management, Vol. 3, No. 1

Webster, Craig and Stanislav Ivanov. 2014. Transforming Competitiveness into Economic 
Benchmarks: Does Tourism Stimulate Economic Growth in More Competitive Destinations ?. Tourism Management 40 137e140

Wei, Shang-Jin. 2000. How Taxing Is Corruption on International Investors ?. Review of Economics and Statistics. 82 (1): 11

Widarjono, Agus. 2018. Econometrics: Introduction and Application Accompanied by the Eviews Guide. Fifth Edition. YKPN STIM UPP. Yogyakarta.

World Bank. 2019. hhtp: //worldbank.org

Zvika, N., M. Daniele, P., Avi, A. 2008. Corruption an Openess. Journal of Economic Analysis and Policy, Vol. 8 